\title{
DAM OPERATION UNDER CHANGING CLIMATE: ANALYSING WATER AVAILABILITY AND HYDROPOWER PRODUCTION FROM MURUM DAM IN SARAWAK
}

\author{
KHAMARUZAMAN WAN YUSOF ${ }^{1}$, MUBASHER HUSSAIN $^{2} \&$ MUHAMMAD RAZA UL MUSTAFA $^{1}$ \\ ${ }^{1}$ Department of Civil and Environmental Engineering, Universiti Teknologi PETRONAS, Sri Iskandar, Malaysia. \\ ${ }^{2}$ Hydro Department, Sarawak Energy Berhad, Kuching, Malaysia.
}

\begin{abstract}
In this study, we assessed the climate change impact on water resources availability and hydropower energy yield from the Murum Dam in Sarawak state of Malaysia. Precipitation ensembles of three general circulation models from Coupled Model Intercomparison Project Phase 5 (CMIP5) were used to simulate daily inflows at Murum Dam for the historical period of 1976-2015 and for the future period of 2011-2100 under two future scenarios (RCP4.5 and RCP8.5). A rainfall-runoff model was developed using Australian Water Balance Model approach to simulate river inflows at Murum Dam. Reservoir operation model was developed using HEC-ResSim to simulate the operation for Murum Reservoir under the historical and future projected inflows. It is noted that the mean river inflow at Murum Dam would increase by $4 \%$ and $11 \%$ during 2080s under RCP4.5 and RCP8.5, respectively. Similar results are noted while simulating the Murum reservoir operation; it is noted that the average annual energy from Murum Hydroelectric Plant would increase by 5\% and 12\% during 2080s under RCP4.5 and RCP8.5, respectively.
\end{abstract}

Keywords: climate change, hydropower, reservoir operation, Sarawak, water resources.

\section{INTRODUCTION}

Hydropower is the major source of global renewable energy production as it is the most economical source of renewable energy. Hydropower integrates very well with the other intermittent renewable energy sources such as wind and solar power to ensure the grid system stability. From 1973 to 2011, it is noted that global energy production from the hydropower plants has increased by $175 \%$ [1]; at the moment, hydropower contributed about $16 \%$ of the globally generated power.

Continuous increase in emission of greenhouse gases to the atmosphere, positive radiative forcing and continuous global surface warming are the indicators of anthropogenic influence on the earth climate system [2]. From 1951 to 2010, global surface temperature increased by $0.5^{\circ} \mathrm{C}$ to $1.3^{\circ} \mathrm{C}$ and due to emission of greenhouse gases, it will cause further warming to change the future global climate system [3]. Climate resilience experts noted that the climate change would also alter the hydrological cycle of river basins as exhibited in [4-10]. There are very few studies conducted in Malaysia which explored the climate change impact on water resource systems such as [11-15]; and they presented notable changes in water resources availability during the 21 st century. Inflow to a dam play a vital role for hydropower production as the water is the fuel to run the hydropower plants. Therefore, in this study we assessed the climate change impact on Murum Dam operation using general circulation models (GCMs) from the Coupled Model Intercomparison Project Phase 5 (CMIP5). The objectives of this paper are: (a) to project the changes in water resources availability at Murum Dam under CMIP5 precipitation projections; and (b) to assess the climate change impact on hydropower energy yield from the Murum Hydroelectric Plant (HEP). 


\section{STUDY AREA AND DATA DESCRIPTION}

\subsection{Study Area}

Murum HEP is the recently commissioned hydro plant in Sarawak state of Malaysia. It is located on the Murum River in upper Rajang river basin (RRB) and regulates about $20 \%$ of the Bakun HEP catchment. The project location map is as shown in Fig. 1. The Murum HEP has total installed capacity 944 MW with four Francis turbines (each of $236 \mathrm{MW}$ ). The Murum Dam is $141 \mathrm{~m}$ high roller compacted concrete gravity dam as shown in Fig. 2. The

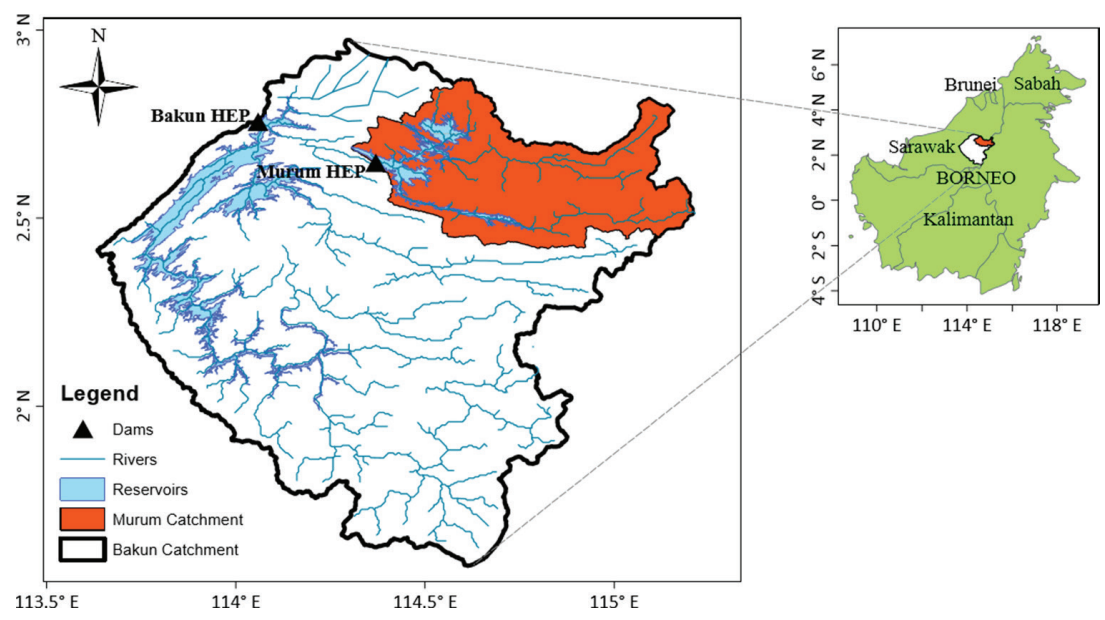

Figure 1: Location of Murum HEP in Sarawak state of Malaysia.

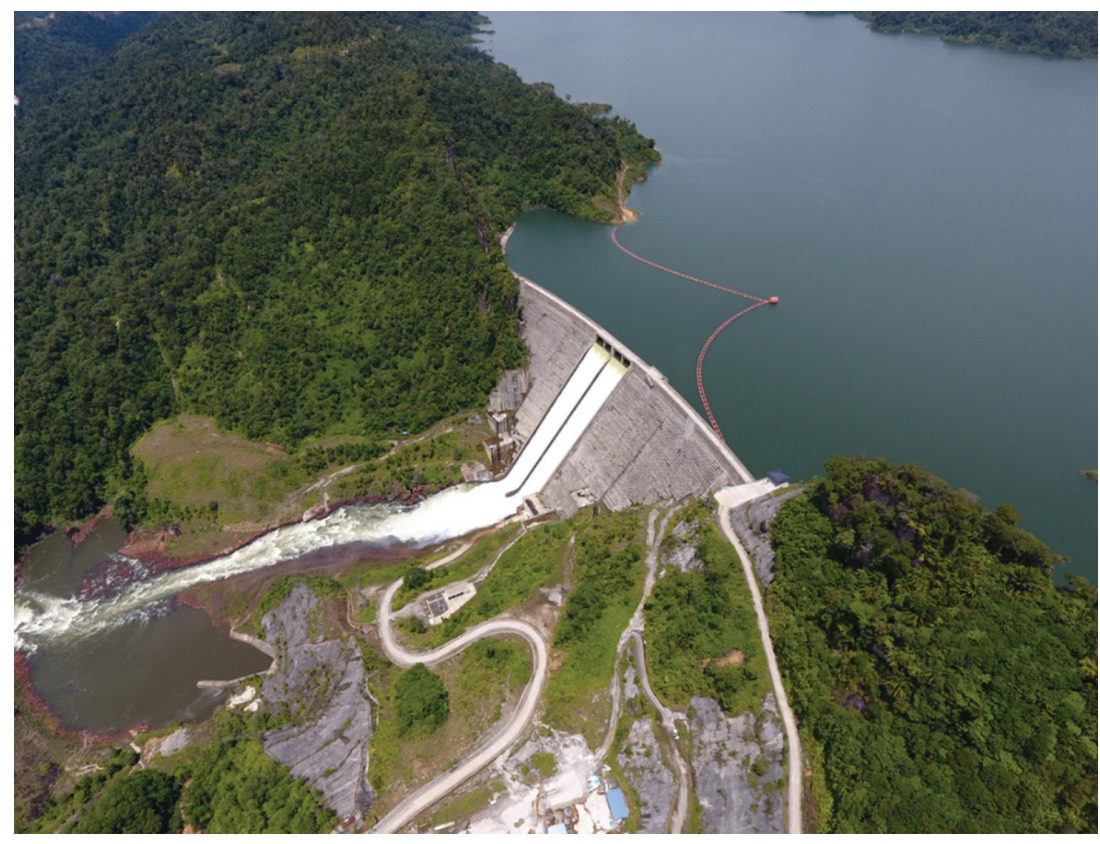

Figure 2: Murum Dam in Sarawak. 
Table 1: CMIP5 models used in the study.

\begin{tabular}{llll}
\hline $\begin{array}{l}\text { CMIP5 } \\
\text { Model }\end{array}$ & Institute & Modelling Group & Country \\
\hline ACCESS1.0 & CSIRO-BOM & $\begin{array}{l}\text { Commonwealth Scientific and Industrial } \\
\text { Research Organization (CSIRO) and Bureau } \\
\text { of Meteorology (BOM), Australia }\end{array}$ & Australia \\
ACCESS1.3 & CSIRO-BOM & $\begin{array}{l}\text { Commonwealth Scientific and Industrial } \\
\text { Research Organization (CSIRO) and Bureau } \\
\text { of Meteorology (BOM), Australia }\end{array}$ & Australia \\
GFDL- & NOAAGFDL & $\begin{array}{l}\text { Geophysical Fluid Dynamics Laboratory, } \\
\text { USA }\end{array}$ & USA \\
\hline
\end{tabular}

Murum dam has the world's tallest stepped spillway structure (54 m wide) with a total discharge capacity of $2160 \mathrm{~m}^{3} / \mathrm{s}$. The Murum HEP has a surface powerhouse connected through $5.5 \mathrm{~km}$ long twin tunnels. A catchment of $2750 \mathrm{~km}^{2}$ drains into the reservoir to provide water resources to the Murum HEP.

\subsection{Data Description}

Daily rainfall record of 11 rainfall stations in the Bakun catchment was acquired from Department of Irrigation and Drainage, Sarawak, for the period of 1976-2005. Twenty GCMs from CMIP5 have been evaluated by Hussain et al. in [16] for their capability to simulate the historical precipitation over the RRB; they noted that the three GCMS (as listed in Table 1) are the most suitable models for the future precipitation projection over the RRB. In this study, we used the precipitation projection of these three models for the river flow projection at the Murum Dam. The precipitation time series for the controlled run (19762005) and future run (2011-2100) were used to simulate the river inflows at Murum dam. For hydrological model calibration, there is no measured flow record available at Murum Dam but recorded inflows are available at the Bakun Dam for the period 2003-2007. The recorded inflows at Bakun Dam were acquired from Sarawak Energy Berhad to develop a rainfall-runoff model.

\section{METHODOLOGY}

\subsection{Hydrological modelling using Aquarius Forecast}

Murum catchment is a sub-basin in the Bakun catchment and river inflows at Bakun Dam are available for the period of 2003 to 2007; therefore, a hydrological model was calibrated at the Bakun Dam and after calibration; the model was run for Murum catchment to simulate the daily inflow at Murum Dam. A rainfall-runoff model for the Bakun catchment was developed using the Australian Water Balance Model approach. Aquarius Forecast tool developed by Aquarius Informatics was used to develop the hydrological model for the Bakun catchment. The meteorological model was established using the Thiessen polygon gauge weight method for precipitation calculation. During the model calibration, the simulated daily inflows were compared (as shown in Fig. 3) with the observed daily inflow using 


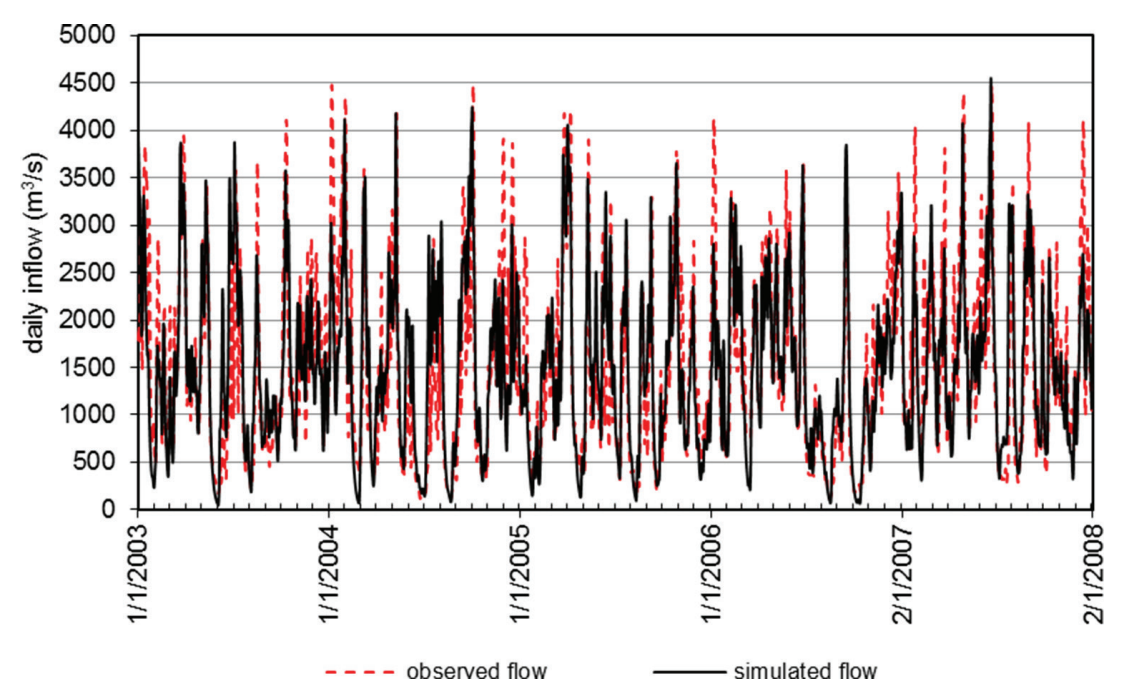

Figure 3: Observed and simulated inflows at Bakun Dam during the Rainfall-Runoff model calibration.

the coefficient of determination $\left(\mathrm{R}^{2}\right)$, per cent deviation (D), and Nash-Sutcliffe efficiency (E). The model's performance parameters-R2, D, and E were calculated using the following equations:

$$
\begin{gathered}
R^{2}=\frac{\sum\left(\left(Q_{o b s}-\bar{Q}_{o b s}\right)-\left(Q_{s i m}-\bar{Q}_{s i m}\right)\right)}{\sqrt{\sum\left(\left(Q_{o b s}-\bar{Q}_{o b s}\right)^{2}-\left(Q_{\text {sim }}-\bar{Q}_{\text {sim }}\right)^{2}\right)}} \\
D=100 \times \frac{\sum\left(Q_{\text {sim }}\right)-\left(Q_{o b s}\right)}{\sum Q_{o b s}} \\
E=1-\frac{\sum\left(Q_{\text {sim }}-Q_{o b s}\right)^{2}}{\sum\left(Q_{o b s}-\bar{Q}_{o b s}\right)^{2}}
\end{gathered}
$$

$\mathrm{R}^{2}$ closer to one, $\mathrm{D}$ closer to zero and the value of $\mathrm{E}$ closer to one indicate the model is well calibrated. In this study, we noted that the coefficient of determination $\left(\mathrm{R}^{2}\right)$ was 0.68 , percent deviation (D) as $0.03 \%$, and Nash-Sutcliffe efficiency (E) as 0.68 for the calibrated model at Bakun. The results were satisfactory as couple of recent studies such as [4, 17-20] have presented similar results while the calibration of hydrological models in various regions. All these studies simulated stream flows for the climate resilience assessment with $\mathrm{R}^{2}$ from 0.63 to 0.84 and $\mathrm{E}$ ranging from 0.48 to 0.83 . After calibration of the rainfall-runoff model, the daily inflow were simulated at the Murum Dam for the historical period 1976-2005 and for the three future period 2011-2040 (2020s), 2041-2070(2050s) and 2071-2100 (2080s). 


\subsection{Reservoir operation modelling for the Murum HEP}

Murum reservoir operation model was developed using HEC-ResSim model. The project features such as reservoir surface area, reservoir storage, dam height, full supply level, minimum operating level, spillway discharge rating, station's installed capacity, turbine rated discharge, turbine efficiency, daily river inflows, environmental flow requirement and monthly evaporation were provided in the reservoir operation model. The plant dispatch rules were defined in the model for the daily power requirement and additional output to avoid spillway discharge as well as to keep the reservoir water level in the optimum operating range. The Murum reservoir operation was simulated on daily basis using the historical inflows for the period of 1976-2005 and for the three future periods under the both RCPs.

\section{RESULTS AND DISCUSSION}

\subsection{River inflows at Murum Dam}

The river inflows at Murum Dam were simulated for the historical period and for the three future periods under the projected precipitation for both climate scenarios i.e. RCP4.5 and RCP8.5. The future projected inflows at Murum Dam were compared with the historical inflows as shown in Fig. 4 and Table 2. It is noted that the mean inflow at Murum Dam would remain same and increase by $4 \%$ during 2020 s; decrease by $2 \%$ and increase by $3 \%$ during 2050s; and increase up to $4 \%$ and $11 \%$ during 2080s under RCP4.5 and RCP8.5, respectively.

The seasonal inflow was also calculated at Murum Dam and seasonal flow variability in context of future climate changes was assessed under both scenarios. It is noted that under RCP4.5, there would be a reduction in December to February (DJF) inflow at Murum Dam during 2050s and 2080s. Under RCP8.5 scenario, considerable increase in March to May (MAM) inflow is noted at Murum Dam during 2080s. For the June to August (JJA), Murum Dam would receive increase in inflow during 2080s of RCP4.5 and during all periods under

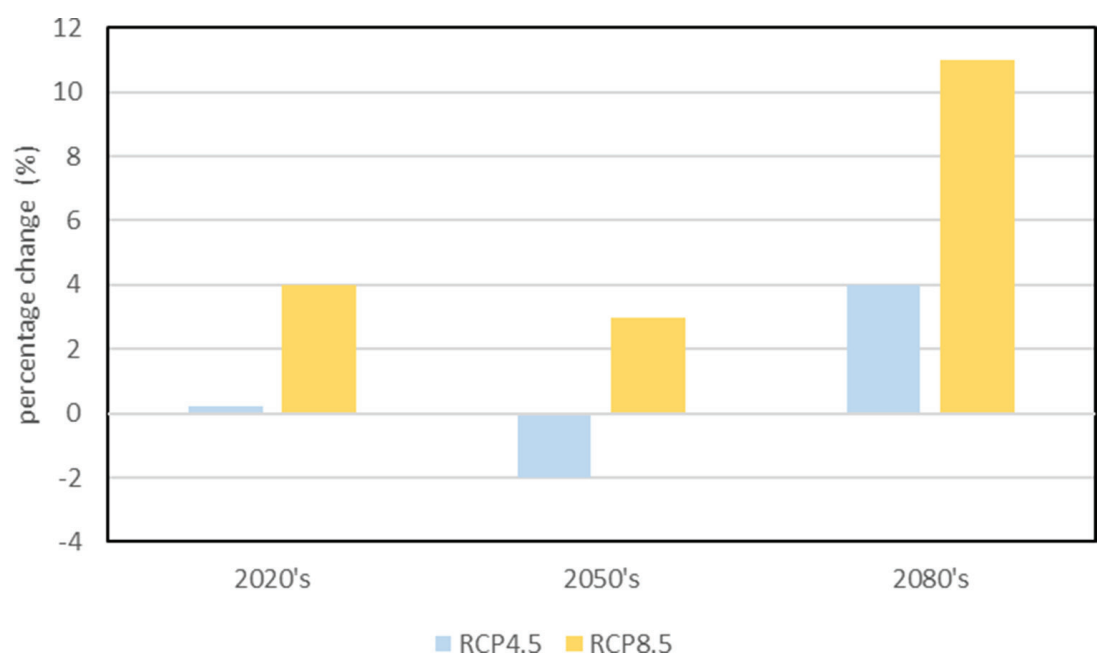

Figure 4: Percentage change in average inflows during the three future periods. 
Table 2: Changes in seasonal availability of water resources at Murum Dam.

\begin{tabular}{lcccccc}
\hline $\begin{array}{l}\text { Future } \\
\text { Scenario }\end{array}$ & \multicolumn{5}{c}{ RCP4.5 } & \multicolumn{3}{c}{ RCP8.5 } \\
Period & 2020s & $\mathbf{2 0 5 0 s}$ & $\mathbf{2 0 8 0 s}$ & $\mathbf{2 0 2 0 s}$ & $\mathbf{2 0 5 0 s}$ & $\mathbf{2 0 8 0 s}$ \\
& & \multicolumn{2}{c}{ Percentage $(\%)$ change in future inflows } & \\
\hline Annual & 0 & -2 & 4 & 4 & 3 & 11 \\
DJF & 3 & -9 & -9 & -1 & -3 & 5 \\
MAM & -4 & 0 & 4 & 10 & 2 & 12 \\
JJA & 2 & 4 & 15 & 7 & 15 & 17 \\
SON & 1 & -4 & 6 & 2 & -3 & 11 \\
\hline
\end{tabular}

RCP8.5. The JJA is the period when the catchment yield lowest inflow in result of lowest precipitation over the catchment. It is noted that the lowest flow during JJA would improve in future. September to November (SON) is the inter monsoon period and this season is the most stable season under future climate scenarios.

MAM is the late North-West monsoon period and receive average rainfall over the Murum catchment, but it is projected that the inflow during this period would also improve in future. But reduction in river inflow in noted during the DJF in the RRB, which indicates that there would be a seasonal shift over the upper RRB in future due to potential climate changes which would result in decrease in inflow during DJF and increase during MAM.

\subsection{Hydropower energy generation from Murum HEP}

The daily power generation from Murum HEP was simulated with the reservoir operation under historical inflows and projected future inflow. The Murum HEP is a base load hydro

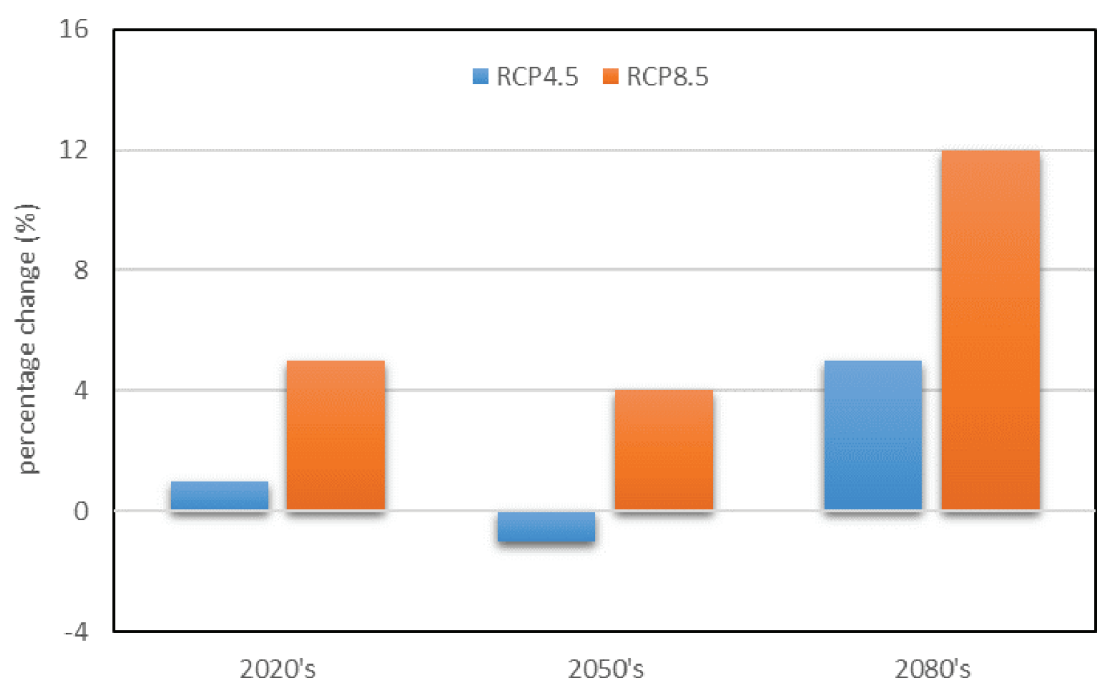

Figure 5: Percentage $(\%)$ changes in future hydropower from Murum HEP. 
plant to supply consistent power to industrial customers. The Murum reservoir operation was simulated with target firm power of $635 \mathrm{MW}$ during the normal operation and full dispatch while the reservoir is at full supply level to mitigate the spilling.

It is noted that the annual energy from Murum HEP would increase by $1 \%$ and $5 \%$ during 2020 s, decrease by $1 \%$ and increase by $4 \%$ during 2050 s and increase by $5 \%$ and $12 \%$ during 2080s under RCP4.5 and RCP8.5, respectively. Significant increase in annual energy is noted during 2080s under RCP8.5 (as shown in Fig. 5) due to projected increase in water resources availability under RCP8.5 of 2080 s.

\section{CONCLUSIONS AND RECOMMENDATIONS}

It is concluded that the mean annual inflow at Murum Dam is expected to increase in future. As the Murum catchment is projected to receive increase in future precipitation especially for the period of 2080s of RCP4.5 and 2050s and 2080s of RCP8.5, therefore, the water resources availability is also increasing during these periods. The projected increase in mean flow under future climate provides water security to the Murum HEP. The plant expect higher increase in hydropower production under RCP8.5 compared to RCP4.5 due to increase in projected inflows under the future climate. The Murum HEP is projected to have $12 \%$ increases in future energy production under RCP8.5.

The hydrological model was developed using the current hydrological behaviour and Murum catchment characteristics. When this model was employed to generate the future inflows under projected precipitation scenarios, it was assumed that the catchment characteristics and hydrological behaviour of the river will be stationary in future. Even though the Sarawak state is less populated and anthropogenic impacts are less but the deforestation in this river basin could affect the hydrological characteristics of the catchment in future. Therefore, there is a need to explore the future changes in the catchment's land use area and its impact on river hydrology.

\section{ACKNOWLEDGEMENTS}

This study is funded by Sarawak Energy Berhad, Malaysia under a climate resilience assessment project. The authors would like to acknowledge the YUTP research grant (cost centre: 015LC0-021). Also, appreciation goes to the Department of Irrigation and Drainage, Sarawak for providing the relevant observed precipitation to conduct this study.

\section{REFERENCES}

[1] Cole, M.A., Elliott, R.J. \& Strobl, E., Climate change, hydro-dependency, and the African dam boom. World Development, 60, pp. 84-98, 2014.

[2] Hassan, M., Du, P., Jia, S., Iqbal, W., Mahmood, R. \& Ba, W., An assessment of the South Asian Summer Monsoon variability for present and future climatologies using a high resolution regional climate model (RegCM4.3) under the AR5 scenarios. Atmosphere, 6(11), pp. 1833-1857, 2015.

[3] IPCC, Summary for Policymakers. In: Climate Change 2013: The Physical Science Basis. Contribution of Working Group I to the Fifth Assessment Report of the Intergovernmental Panel on Climate Change, eds. T.F. Stocker, D. Qin, G.K. Plattner, M. Tignor, S.K. Allen, J. Boschung, A. Nauels, Y. Xia, V. Bex, \& P.M. Midgley, Cambridge University Press: Cambridge, United Kingdom and New York, NY, USA., 2013.

[4] Mahmood, R., Jia, S. \& Babel, M., Potential impacts of climate change on water resources in the Kunhar river basin, Pakistan. Water, 8(1), p. 23, 2016.

[5] Hidalgo, H.G., Amador, J.A., Alfaro, E.J. \& Quesada, B., Hydrological climate change projections for Central America. Journal of Hydrology, 495, pp. 94-112, 2013. 
[6] Zhang, C., Zhang, B., Li, W. \& Liu, M., Response of streamflow to climate change and human activity in Xitiaoxi river basin in China. Hydrological Processes, 28, pp. 43-50, 2014.

[7] Kienzle, S.W., Nemeth, M.W., Byrne, J.M. \& MacDonald, R.J., Simulating the hydrological impacts of climate change in the upper North Saskatchewan River basin, Alberta, Canada. Journal of Hydrology, 412-413, pp. 76-89, 2012.

[8] Chang, H. \& Jung, I.W., Spatial and temporal changes in runoff caused by climate change in a complex large river basin in Oregon. Journal of Hydrology, 388(3-4), pp. 186-207, 2010.

[9] Grillakis, M.G., Koutroulis, A.G. \& Tsanis, I.K., Climate change impact on the hydrology of Spencer Creek watershed in Southern Ontario, Canada. Journal of Hydrology, 409(1-2), pp. 1-19, 2011.

[10] Khadka, D., Babel, M.S., Shrestha, S. \& Tripathi, N.K., Climate change impact on glacier and snow melt and runoff in Tamakoshi basin in the Hindu Kush Himalayan (HKH) region. Journal of Hydrology, 511, pp. 49-60, 2014.

[11] Amin, M.Z.M., Shaaban, A.J., Ohara, N., Kavvas, M.L., Chen, Z.Q., Kure, S. \& Jang, S., Climate change assessment of water resources in Sabah and Sarawak, Malaysia, based on dynamically-downscaled GCM projections using a regional hydroclimate model. Journal of Hydrologic Engineering, 21(1), 2016.

[12] Tan, M.L., Ficklin, D.L., Ibrahim, A.L. \& Yusop, Z., Impacts and uncertainties of climate change on streamflow of the Johor River Basin, Malaysia using a CMIP5 General Circulation Model ensemble. Journal of Water and Climate Change, 5(4), pp. 676-695, 2014.

[13] Mustafa, M.R., Hussain, M. \& Yusof, K.W., Climate change impact on water resources of Bakun hydroelectric plant in Sarawak, Malaysia. Proceedings of the 3rd International Conference on Civil, Offshore and Environmental Engineering, 283(287), pp. 283-287, 2016.

[14] Hussain, M., Nadya, S., Yusof, K.W. \& Mustafa, M.R., Potential impact of climate change on inflows to the Batang Ai reservoir, Malaysia. The International Journal on Hydropower \& Dams, 24, pp. 44-48, 2017.

[15] Hussain, M., Yusof, K.W., Mustafa, M.R., Mahmood, R. \& Shaofeng, J., Projected changes in temperature and precipitation in Sarawak state of Malaysia for selected CMIP5 climate scenarios. International Journal of Sustainable Development and Planning, 12(8), pp. 1299-1311, 2017.

[16] Hussain, M., Yusof, K.W., Mustafa, M.R.U., Mahmood, R. \& Jia, S., Evaluation of CMIP5 models for projection of future precipitation change in Bornean tropical rainforests. Theoretical and Applied Climatology, 2017.

[17] Meenu, R., Rehana, S. \& Mujumdar, P.P., Assessment of hydrologic impacts of climate change in Tunga-Bhadra river basin, India with HEC-HMS and SDSM. Hydrological Processes, 27(11), pp. 1572-1589, 2013.

[18] Verma, A.K., Jha, M.K. \& Mahana, R.K., Evaluation of HEC-HMS and WEPP for simulating watershed runoff using remote sensing and geographical information system. Paddy and Water Environment, 8(2), pp. 131-144, 2010.

[19] Yimer, G., Jonoski, A. \& Griensven, A.V., Hydrological response of a catchment to climate change in the Upper Beles River Basin, Upper Blue Nile, Ethiopia. Nile Basin Water Engineering Scientific Magazine, 2, pp. 49-59, 2009.

[20] García, A., Sainz, A., Revilla, J.A., Álvarez, C., Juanes, J.A. \& Puente, A., Surface water resources assessment in scarcely gauged basins in the north of Spain. Journal of Hydrology, 356(3-4), pp. 312-326, 2008. 